\title{
The relationship between IPOs and long-term industry performance: Evidence from Tehran Stock Exchange
}

\author{
Mohsen Sohrabi ${ }^{a}$, Rahman Biglar ${ }^{\mathrm{b} *}$ and Mohammad Mehdi Jamshidian ${ }^{\mathrm{b}}$
}

${ }^{a}$ Assist Prof, Department of Management and Accounting, Allameh Tabataba'i University, Tehran, Iran ${ }^{b}$ Department of Management and Accounting, Allameh Tabataba'i University, Tehran, Iran

\section{CHRON I C L E}

Article history:

Received May 12, 2013

Received in revised format

12 August 2013

Accepted 28 September 2013

Available online

October 12013

Keywords:

Initial Public Offering

Return Of Buy-Hold Portfolio

Return Of Buy-Hold Market

Abnormal Return Of Buy-Hold

Portfolio

\begin{abstract}
A B S T R A C T
Every year, the companies with favorable perspective are entered into stock exchange through Initial public offering (IPO). This issue is a treat for share of competitors in market and usually, IPO is offered while industry is in top of its valuation, which could be corrected after offering price. In this regard, we study the relationship between IPO and long-term performance of industry, identification and explaining the effective factors. In addition, the relationship of IPS has compared with portfolios of corresponding competitors. In this study, we conclude that the portfolios of competitors had an undesirable performance three years after initial offering. Six effective variables are verified on performance including industry concentration, industry valuation and homogeneity, size of offering, industry operating leverage and industry financial leverage. Undesirable effects of industry is specified when the industry valuation is rather high, industry is in top of valuation or concentration is high in industry, also, when the homogeneity of industry is more, undesirable effect is less.
\end{abstract}

\section{Introduction}

An initial public offering (IPO) may be considered as an opportunity for many investors to take part in the ownership of a growing firm. However, to the extent that an initial public offering is also timed to please the founders, venture capitalists, or other existing owners, it may have negative repercussions for new investors. Some studies indicate that IPOs generate high initial (1-day) returns at the time of offering, but tend to provide weak aftermarket returns. The weak aftermarket returns could be due to IPO-specific conditions, such as the inability to manage growth, or poor implementation of proceeds resulting from the IPO. Alternatively, the weak aftermarket returns could 
be because of relatively weak industry conditions when IPOs are timed near the peak of the industry's relative performance.

To the best of our knowledge, there is not any similar study performed about research background and perhaps the nearest research to this study is associated with a research with topics of verifying the impact of industry, market condition, and behavior factors of investors on return of IPO share in exchange including Tehran Stock Exchange (TSE). In this study, the primary objective is to study newly accepted behavior on a market with a long-term swing and to verify effective factors on short term return of IPO. This is accomplished by considering different variables such as industry, expansion or contraction of market and behavior factors of investors. In other studies, the effective factors on earnings abnormal returns on IPO by various factors such as presence of offered shares, $\mathrm{P} / \mathrm{E}$ ratio, ownership ratio of major participants and rate of companies' capital in time of abnormal offering time have been already examined. Akhigbe et al. (2006), for instance, performed an investigation on US stock exchange and verified the long-term performance of industry after IPOs by examining 2483 IPO in 68 industries. Some studies showed that financial status of a company could send a good signal about industry perspective or degree of competition inside industry. Cheng and McDonald (1996) specified the epidemic effects for declaration of railway bankruptcy. They also showed the competition effects for bankruptcy declarations by airline companies. Docking et al. (1997) showed the epidemic effects in response to reduce loan reserve declaration. Other studies showed that a bad situation for a company could reduce the expected competition rate inside industry. Lang and Stulz (1992) reported the competition impacts in response to time failure declarations in which the competition rate and financial lever rate were low among competitors. They evaluated the effects of inter-industry of share offering in secondary market. They reported that when foreign investors were involved in offering in secondary market, we could draw an undesirable status about company. Akhigbe et al. (2003) did not find any effect of inter-industry on response to IPOs.

Farino et al. (2007) investigated the operating and stock market performance of Spanish state-owned enterprises (SOEs) privatized through public share issue offerings (SIPs) from 1990 to 2001, when the last SIP was conducted. They compared the performance of SOEs and privately-owned companies and reported significant operating improvements in Spanish SOEs after the privatization. Hovey and Li (2007) investigated whether IPO underpricing in China could explain a firm's longterm performance or not by examining of IPOs in China with Corporate Governance Perspectives. They showed that IPOs have better return with positive initial return in long term. Outside organization ownership and major shareholders ownership had a positive effect on long term performance of IPOs. Governmental ownership before IPOs could reduce long-term performance of IPOs. The size of company and possibility of potential growth in long term had a positive impact on company assessment and long term performance. Modares and Asgari (2010) specified the effective factors on long-term abnormal return of initial public offering share among TSE firms. They verified the existence of abnormal return in shares of new entered companies TSE firms and some possible factors. They reported a positive abnormal return during 24 months after IPSs of companies' shares.

The purpose of this study is to investigate the effects of long-term industry return after IPOs. IPOs may have favorable or unfavorable impact on the return of the industry. To understand the effects of these factors on long-term return of the industry, different variables such as concentration, industry valuation and homogeneity, size of offering, industry operating leverage and industry financial leverage will be measured. We offer an initial research to explain the relationship between long-term return of the industry and the way Akhigbe et al. (2006) used it in the U.S. They also used Fama and French method (1993) for measuring these factors.

The scientific contribution of this paper are: 1) Explaining the relationship between IPO and longterm return of the corresponding industry. 2) Identifying the factors affecting the return of the industry during IPO. 3) Assisting investors in investment decisions. 4) To help investment bank managers value and time the IPO's. 
Research methodology is described in the next section; in this section, initially we specified the research hypotheses and variables, methods of data collection and the research model. The findings are discussed in the third section and the results are presented last.

\section{Methodology}

\subsection{Research hypothesis}

The public offering includes offering share or other financial tools by an organization to people in order to supply required cash for investment and activity development and there must be at least 35 people interested in purchasing the shares. The offering price is determined by offering company and the company supplying capital is responsible for transactions. If, the public offering is performed for the first time, it is called the initial public offering.

1. There is a significant relationship between long-term performance and IPOs.

2. There is a relationship between the Size of offering and long-term performance of industry after offering

3. There is a relationship between homogeneity of industry and long-term performance of industry after Initial Public Offering

4. There is relationship between industry concentrations and long-term performance of industry after Initial Public Offering

5. There is relationship between Industry financial leverage and long-term performance of industry after Initial Public Offering

6. There is relationship between Industries operating leverage and long-term performance of industry after Initial Public Offering.

7. There is relationship between Industry valuation and long-term performance of industry after Initial Public Offering

\subsection{Research variables}

In this study, the abnormal variable return of Buy-Hold the portfolio of industry is considered as dependent variable. Variable of Buy-Hold market return are independent variable of this research which in this study, this independent variable is verified on dependent variable. We next measure and verify each of variable and manner of calculating it.

a)The return of Buy-Hold of industry: To calculate return of Buy-Hold portfolios of competitor ( portfolio of each industry), first, we consider related index and collect related daily data for a three years period and then we calculate their daily return and finally calculate the return of Buy-Hold with geometric averaging for each portfolio of industry.

$\mathrm{BHR}_{\mathrm{p}}=\prod_{\mathrm{t}=1}^{\tau}\left[1+\mathrm{R}_{\mathrm{pt}}\right]-1$

b) Return of Buy-Hold of market: To calculate this variable, we examine the rate of daily index for a period and calculate the daily return and then the return of Buy-Hold and geometric average achieved by return are calculated. The formula is as follows,

$\mathrm{BHR}_{\mathrm{m}}=\prod_{\mathrm{t}=1}^{\tau}\left[1+\mathrm{R}_{\mathrm{mt}}\right]-1$ 
In conclusion, the abnormal return of Buy-Hold portfolio of industry is achieved as follows,

$$
\mathrm{BHAR}_{\mathrm{p}}=\mathrm{BHR}_{\mathrm{pt}}-\mathrm{BHR}_{\mathrm{mt}}
$$

\subsection{Sectional effects of industries}

Developed scattering of abnormal return BHAR of industries may lead to a false conclusion in which all IPSs are scheduled so that it would be offered in more unfavorable condition in corresponding industries.

1) The Size of offering: the size of offering dividing by market value of offering on market value portfolio of corresponding industry.

2) Homogeneity of industry: with correlation coefficient of daily return among Initial Public Offerings and portfolio of corresponding industry in 250 transactional days measured after Initial Public Offering

3) Industry concentration: appoint to entering new companies to industries. Whatever entering to industry is more difficult, industry concentration is higher. This variable is calculated by Herfindahl index (total squares of sale ratio of competition companies in industry). Whatever this ratio is higher, the concentration will be higher.

4) Industry financial leverage: the result of long-term debts divided on total assets.

5) Industry operating leverage: operational lever include the percent of operational profit changes divided on percent of sales changes.

6) Industry valuation: is achieved by price coefficient division / profit on coefficients average in last three years

In this study, the available data related to shares of listed companies in TSE over the period 19992009 were considered. The sample is selected by members of community subject to the following conditions:

1-The IPOs must be between the years of 1999-2009.

2-The sample is selected from industries where at least one company had been active in that industry prior to IPOs.

\subsection{How to collect data}

To collect required data for this study, the study has gathered the necessary information from official financial information disclosed to TSE.

\subsection{Research model}

According to research hypothesis, there is a significant relationship between abnormal return of BuyHold of market and return of Buy-Hold portfolio of industry. We intend to examine this relation by using of a linear regression model as following:

$$
B H A R p=a+B H R p+U
$$

$\mathrm{H}_{0}: \beta=0$

$\mathrm{H}_{1}: \beta \neq 0$ 
Before estimating variables, we need to verify normality of the dependent variable by using of Shapiro and Wilk test, which is equal to 0.086. Since, the observations number are less than 100 , Shapiro and Wilk test are the criterion of deciding. In conclusion, the normality hypothesis of this variable is not rejected. It means that, the variable distribution of abnormal return of Buy-Hold portfolio of industry is normal.

1) The Size of offering: The size of offering is achieved by market value division of IPOs on market value portfolio of corresponding industry.

2) Homogeneity of industry: Homogeneity of industry is measured by correlation coefficient of daily productivities between IPOs and portfolio of corresponding industry in 250 transactional days after IPOs.

3) Industry concentration: appoint to new companies entered to industry. Whatever the entrance to industry is more difficult, the industry concentration is higher. This variable is calculated by Herfindahl index (total squares of sale ratio of competition companies in industry). Whatever this ratio is higher, the concentration will be higher.

4) Industry financial leverage: The result of long-term debts divided by total assets.

5) Industry operating leverage: Operational lever include the percent of operational profit changes divided by percent of sales changes.

6) Industry valuation: This ratio is achieved by price coefficient division divided by profit on coefficients average in last three years

\subsection{Community and research statistical sample}

In this study, the information are collected from the financial statement disclosed to TSE over the period 1999-2009. The sample is selected by members of community subject to the following conditions:

1-The IPOs must have happed between 1999 and 2009.

2-The sample was selected by industries where at least one similar firm had been accepted.

\subsection{How to collect data}

To collect required data for this study, the study used official financial reports of companies disclosed to TSE.

\section{Findings}

In Table 1, the central index such as average, middle, dispersion index include standard deviation, elongation and skewness are calculated for different variables. According to the results of Table 1, the elongation of abnormal return of Buy-Hold portfolio of industry is more than normal elongation.

Table 1

The summary of basic statistics associated

\begin{tabular}{|c|c|c|c|c|c|c|c|c|c|}
\hline Variable name & number & average & middle & $\begin{array}{l}\text { Criterion } \\
\text { deviation }\end{array}$ & $\begin{array}{l}\text { Skewness } \\
\text { coefficient }\end{array}$ & $\begin{array}{l}\text { Elongation } \\
\text { coefficient }\end{array}$ & first & second & third \\
\hline $\begin{array}{l}\text { Return of Buy-Hold portfolio } \\
\text { of market }\end{array}$ & 80 & 1.486 & 1.040 & 0.9409 & 0.789 & 1.375 & .797 & 1.040 & 1.818 \\
\hline $\begin{array}{l}\text { Abnormal return of Buy-Hold } \\
\text { portfolio of industry }\end{array}$ & 80 & -.0795 & $-0,1700$ & 1.08287 & .002 & .158 & -.5975 & -.5975 & .4825 \\
\hline
\end{tabular}




\subsection{Normality test among dependent variables distribution}

Before we perform any statistical analysis, we need to make sure about the normality of the data. Table 2 demonstrates the summary of the implementation of Kolmogrof-Smirnof and Shapiro Wilk tests.

\section{Table 2}

The summary of Kolmogrof-Smirnof and Shapiro Wilk

\begin{tabular}{lcccc}
\hline Description & \multicolumn{2}{c}{ Kolmogrof-Smirnof } & \multicolumn{2}{c}{ Shapiro Wilk } \\
Statistics name & Statistics amount & Significant level & Statistics amount & Significant level \\
\hline $\begin{array}{l}\text { Abnormal return of Buy- } \\
\text { Hold portfolio of industry }\end{array}$ & 0.100 & 0.046 & 0.973 & 0.086 \\
\hline
\end{tabular}

Since, the abnormal return of Buy-Hold portfolio of industry was not normal, we removed 8 missing observations to achieve the normal observations. The amount of significant possibility for abnormal return of Buy-Hold portfolio of industry in Kolmogrof Smirnof test was 0.046 and in Shapiro Wilk test was 0.086 . Because the number of observations is few than 100, the Shapiro Wilk test was the criterion of deciding and in conclusion the normality hypothesis was not rejected. It means that the variable abnormal distribution of Buy-Hold portfolio of industry is normal. Fig. 1 shows the histogram of the data, which looks like a normal distribution.

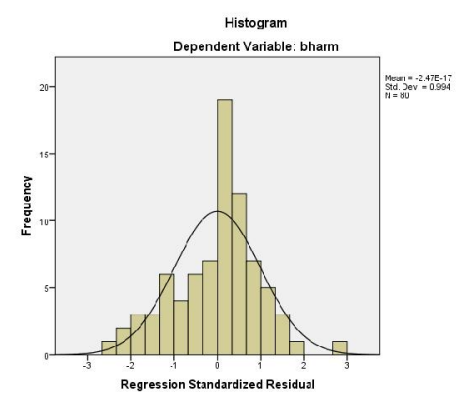

Fig. 1. Examining the normality of abnormal return of Buy-Hold portfolio of industry

\subsection{Examining the correlation coefficient in variables}

In the below correlation matrix, the correlation rate of Pierson is calculated between dependent and independent variable. The rate of variable correlation is written in null hypothesis as follows,

\section{$\mathrm{H}_{0}: \mathrm{PXY}=0$}

$\mathrm{H}_{1}: \mathrm{PXY} \neq 0$

Correlation matrix of Pierson is calculated in Table 3 and the conclusions are as following:

\section{Table 3}

The results of Pearson correlation test between abnormal return of buy-hold and return of buy-hold

\begin{tabular}{llcc}
\hline & & $\begin{array}{c}\text { Abnormal return of Buy- } \\
\text { Hold portfolio of industry }\end{array}$ & $\begin{array}{l}\text { Return of Buy-Hold } \\
\text { portfolio of market }\end{array}$ \\
\hline Coefficients amount & Abnormal return of Buy-Hold portfolio of industry & 1 & -0.401 \\
& return of Buy-Hold portfolio of market & -0.401 & 1 \\
\hline Significant level & Abnormal return of Buy-Hold portfolio of industry &. & 0 \\
& return of Buy-Hold portfolio of market & 0 &. \\
\hline number & Abnormal return of Buy-Hold portfolio of industry & 80 & 80 \\
& return of Buy-Hold portfolio of market & 80 & 80 \\
\hline
\end{tabular}


The rate of correlation between Return of Buy-Hold portfolio of market and Abnormal return of Buyhold portfolio of industry is equal to -0.401 , which is negative and significant.

Table 4

Model summary

\begin{tabular}{llllll}
\hline Model & Correlation coefficient & $\begin{array}{l}\text { Determination } \\
\text { coefficient }\end{array}$ & $\begin{array}{l}\text { Modulated determination } \\
\text { coefficient }\end{array}$ & $\begin{array}{l}\text { Estimation } \\
\text { criterion deviation }\end{array}$ & Camera-Watson \\
\hline 1 & $-0,401$ & 0.16 & 0.15 & 0.998 & 1.801 \\
\hline
\end{tabular}

\subsection{Testing of being significant average of sample}

In this part, we perform a significant test in order to examine to 5 main questions of research. By using of t-student test. The hypothesis of this test is as following:

$\mathrm{H}_{0}: \mu=0$

$\mathrm{H}_{1}: \mu \neq 0$

Table 5

Average significant test

\begin{tabular}{ccccccc}
\hline & $\begin{array}{l}\text { Statistics } \\
\text { amount }\end{array}$ & $\begin{array}{l}\text { Freedom } \\
\text { degree }\end{array}$ & Significant level & $\begin{array}{l}\text { Average } \\
\text { difference }\end{array}$ & Down limit & Up limit \\
\hline $\begin{array}{c}\text { Abnormal return of buy-hold } \\
\text { portfolio of industry }\end{array}$ & -657 & 79 & 513 & -0.0795 & -0.0721 & 0.1615 \\
\hline
\end{tabular}

According to t-test computed, the hypothesis $\mathrm{H}_{0}$ is rejected and by considering the rate, it is specified that community average is less than zero.

\subsection{Examination and subsidiary hypothesis test of research}

In this part, the Pierson test is performed between each of subsidiary hypothesis variables and dependent variable (abnormal return of buy-hold). Table 6 summarizes the results of our survey.

\section{Table 6}

The results of Pearson correlation between Abnormal return of buy-hold and other variables

\begin{tabular}{lcccccccc}
\hline & $\begin{array}{c}\text { Abnormal return of buy- } \\
\text { hold portfolio of industry }\end{array}$ & $\begin{array}{c}\text { The Size of } \\
\text { offering }\end{array}$ & $\begin{array}{c}\text { Industry } \\
\text { concentration }\end{array}$ & $\begin{array}{c}\text { Industry } \\
\text { operating } \\
\text { leverage }\end{array}$ & $\begin{array}{c}\text { Industry } \\
\text { financial } \\
\text { leverage }\end{array}$ & $\begin{array}{c}\text { Industry } \\
\text { valuation }\end{array}$ & $\begin{array}{c}\text { Industry } \\
\text { homogeneity }\end{array}$ \\
\hline $\begin{array}{l}\text { Pierson correlation } \\
\text { coefficient }\end{array}$ & 1 & -108 & 115 & -178 & 032 & 092 & -173 \\
$\begin{array}{l}\text { Significant level } \\
\text { Observations number }\end{array}$ & 80 & 340 & 009 & 113 & 777 & 037 & 025 \\
\hline
\end{tabular}

According to the results of Table 6, we observe that significant level for IPOs size of variables, Industry operating leverage and financial lever is more than 0.05 . Therefore, correlation coefficient for these variables are not significant and for industry concentration variables, Industry valuation and Industry homogeneity is significant. According to Pierson correlation coefficient of each variable, we observe that there is a direct relationship between abnormal return of Buy-Hold portfolio of industry with industry concentration and Industry valuation. In addition, there is an inverse relationship between abnormal return of buy-hold portfolio of industry with Industry homogeneity.

\section{Discussion and conclusion}

In this research, we have used the financial information of TSE listed companies over the period of 19992009. The hypotheses of this study were in two general states and they were separated by effective factors on test industry performance. In general state, the results of regression test showed that there was 
an inverse and direct relationship between abnormal return of Buy-Hold portfolio of industry and BuyHold return portfolio of market. In this study, we concluded that competitors' portfolios had undesirable performances in 3 years after IPO in that industry. It is specified that industry concentration and Industry valuation had positive and significant correlation coefficient with abnormal return of Buy-Hold portfolio of industry. We also showed whenever the industry coefficient was higher and industry was on top and concentration of industry was higher, the performance was unfavorable. In addition, Industry homogeneity had negative and significant correlation coefficient with abnormal return of Buy-Hold portfolio of industry showing whenever the homogeneity in industry was higher, unfavorable effect of IPO was less on industry.

\section{References}

Akhigbe, A., Borde, S. \& Whyte, A. (2003). Does an industry effect exist for IPOs? Financial Review, 38(4), 531-551.

Akhigbe, A., Johnston, J., \& Madura, J. (2006). Long-term industry performance following IPOs. The Quarterly Review of Economics and Finance, 46(4), 638-651.

Amadpour, A., \& Rahmani firozjai, M. (2007). The effect of firm size and the ratio of book value to market value of the stock returns (Tehran Stock Exchange). Economic Research, 79.

Angbazo, L. A., \& Narayanan, R. (1996). Catastrophic Shocks in the property-liability insurance industry: Evidence on regulatory and contagion effects. Journal of Risk and Insurance, 63, 619637.

Cheng, L. T.W., \& McDonald, J. E. (1996). Industry structure and ripple effects of bankruptcy announcements. Financial Review, 31, 783-807.

Docking, D. S., Hirschey, M., \& Jones, E. (1997). Information and contagion effects of bank loan loss announcements. Journal of Financial Economics, 43, 219-239.

Fama, E. F., \& French, K. R. (1993). Common risk factors in the returns on stocks and bonds. Journal of financial economics, 33(1), 3-56.

Farinos, J. E., Garcia, C. J., \& Ibanez, A. M. (2007). Operating and stock market performance of state-owned enterprise privatizations: the Spanish experience. International Review of Financial Analysis, 16(4), 367-389.

Hovey, M., \& Li, L. (2007). Does IPO Underpricing in China Explain a Firm's Long-Term Performance? An Empirical Study of IPOs in China with Corporate Governance Perspectives. An Empirical Study of IPOs in China with Corporate Governance Perspectives (January 1, 2009).

Initial public offerings (2009), Stock Exchange, Department of Economic Research and Market Development.

Khabari Zad., M. (2011). Factors Affecting earn abnormal returns in the initial public offering, thesis of masters, Tabatabai University.

Lang, L. H. P., \& Stulz, R. M. (1992). Contagion and competitive intra-industry effects of bankruptcy announcements: An empirical analysis. Journal of Financial Economics, 32, 45-60.

Modares, A., \& Asgari, M, (2010), Identify factors influencing long-term abnormal returns of initial public offering of shares in the Tehran Stock Exchange. Stock Exchange Quarterly, 5.

Ritter, J. R. (1991). The long-run performance of initial public offerings. The journal of finance, 46(1), 3-27.

http://www.irbourse.com

http://www.rdis.ir

http://www.seo.ir 